\title{
POTENSI DAN TINGKAT PEMANFAATAN IKAN LAYANG (Decapterus sp) DI PERAIRAN PULAU TERNATE
}

\author{
Mujais B. Sangaji*, Umar Tangke ${ }^{* *}$, Djabaludin Namsa** \\ *Alumni THP UMMU-Ternate, Email : \\ Staf Pengajar FAPERTA UMMU-Ternate, Email: khakafart@yahoo.com
}

\begin{abstract}
ABSTRAK
Wilayah perairan Pulau Ternate memiliki sumberdaya ikan yang berlimpah dan beraneka ragam, data statistik tahun 2013 menunjukkan bahwa terjadi peningkatan produksi dan jumlah nelayan untuk melakukan penangkapan jenis ikan ekonomis penting. Seiring dengan meningkatnya jumlah penduduk serta kebutuhan pangan dan gizi yang lebih baik akan sangat memacu tingkat permintaan ikan yang tentu akan berpengaruh positif bagi peningkatan pendapatan nelayan, namun perlu disadari bahwa peningkatan permintaan sumberdaya tersebut selalu diikuti tekanan untuk melakukan eksploitasi. Sampai tahun 2015 hasil tangkapan khususnya ikan layang (Decapterus sp) di Perairan Pulau Ternate telah mencapai 336,480.29 Ton. Melihat jumlah produksi sumberdaya yang ada, maka tentunnya pengelolaan perikanan menjadi alat yang sangat penting untuk menjaga keberlanjutan sumberdaya ini. Penelitian ini bertujuan untuk menganalisis Potensi Lestari (Maximum Sustainable Yield) dan Upaya pemanfaatan optimum, tingkat pemanfaatan serta produksi CPUE, dari tahun 2008 sampai 2015 dan hasil penelitian diharapkan dapat dijadikan bahan pertimbangan dalam pengelolaan ikan layang (Decapterus sp) secara berkelanjutan di perairan PulauTernate, Provinsi Maluku Utara. Hasil penelitian menunjukan bahwa besarnya potensi lestari (MSY) ikan layang (Decapterus sp) di perairan Pulau Ternate adalah sebesar 311,516.493 ton/tahun dengan upaya maksimum (F-Opt) adalah 10,765.155 trip/tahun. Untuk tingkat pemanfaatan maksimum yang di ijinkan adalah sebesar $80 \%$ dari MSY sehingga tingkat pemanfaatan maksimumnya yang dianjurkan adalah sebesar 249,205.19 ton/tahun.
\end{abstract}

Kata Kunci : Decapterus sp, Perairan Pulau Ternate, MSY

\section{PENDAHULUAN}

1.1. Latar Belakang

Sumberdaya ikan perlu di kelola karena merupakan sumberdaya hayati yang dapat diperbaharui (renewable), namun dapat mengalami kepunahan. Sumberdaya ikan memiliki kelimpahan yang terbatas, sesuai dengan daya dukung (carryng capacity) habitatnya. Sumberdaya ikan dikenal sebagai sumberdaya milik bersama (common property) yang rawan terhadap tangkap lebih (over fishing) (Monintja, 2001). Dengan demikian, mengelola suatu sumberdaya ikan dengan cara yang benar dan tepat adalah suatu keharusan. Tujuan utama pengelolaan sumberdaya perikanan ditinjau dari segi biologi adalah upaya konservasi stok ikan untuk menghindari lebih tangkap (King \& llgorm, 1989). Dalam eksplorasi dan eksploitasi sumberdaya perikanan, diperlukan dugaan potensi sumberdaya perikanan yang dapat memberi gambaran mengenai tingkat dan batas maksimal dalam pemanfaatan sumberdaya perikanan di suatu wilayah.

Wilayah perairan Pulau Ternate (Gambar 1) memiliki sumberdaya ikan yang berlimpah dan beraneka ragam, data statistik tahun 2013 menunjukkan bahwa terjadi peningkatan produksi dan jumlah nelayan untuk melakukan penangkapan jenis ikan ekonomis penting. Seiring dengan meningkatnya jumlah penduduk serta kebutuhan pangan dan gizi yang lebih baik akan sangat memacu tingkat permintaan ikan yang tentu akan berpengaruh positif bagi peningkatan pendapatan nelayan, namun perlu disadari bahwa peningkatan permintaan sumberdaya tersebut selalu diikuti tekanan untuk melakukan eksploitasi.

Ikan layang (Gambar 2) atau lebih dikenal dengan nama ilmiah Decapterus sp 
merupakan salah satu komunitas perikanan pelagis kecil yang penting di Indonesia khususnya di perairan Pulau Ternate. Ikan termasuk suku Carangidae ini biasa hidup bergerombol. Ukurannya sekitar 15 centimeter meskipun ada pula yang bisa mencapai 25 centimeter. Ciri khas yang sering dijumpai pada ikan layang ialah terdapatnya sirip kecil (finlet) di belakang sirip punggung dan sirip dubur dan terdapat sisik berlingin yang tebal (lateral scute) pada bagian garis sisi (lateral line) (Nontji, 2002).
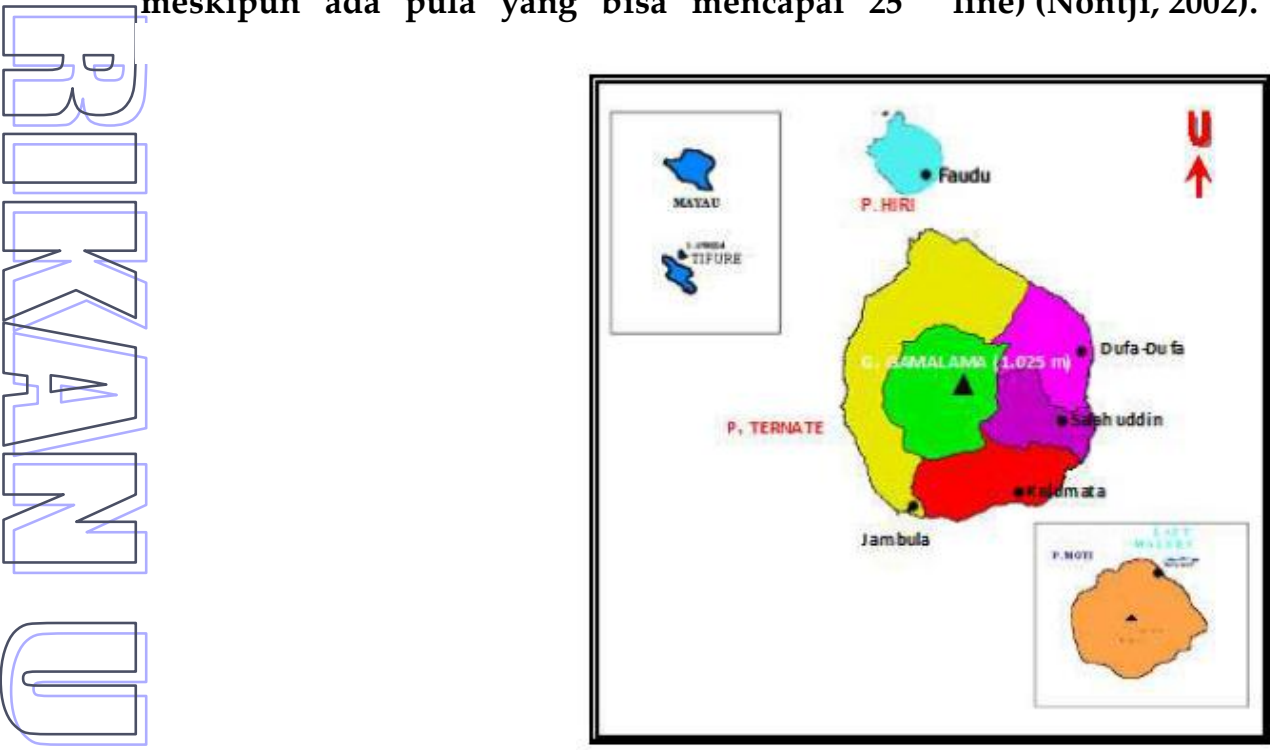

Gambar 1. Peraiarn Pulau Ternate

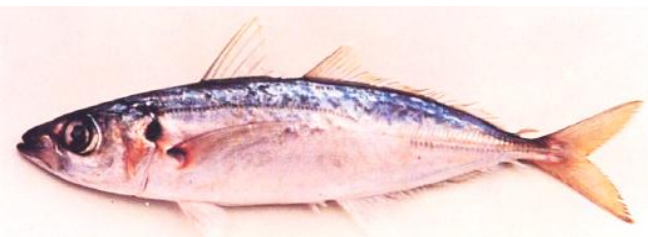

Gambar 2. Ikan Layang Biasa (Decapterus sp)

Besarnya potensi sumber daya kelautan dan perikanan tidak serta merta tanpa persoalan. Isu kemiskinan nelayan, misalnya, telah menjadi isu struktural sejak lama bagi pengelolaan (governance) sektor kelautan dan perikanan. Pada saat yang sama, isu rusaknnya sumberdaya alam perikanan dan kelautan pula pun telah lama diketahui, misalnya gejala overfishing di perairan Indonesia. Meski demikian, potensi sumber daya kelautan dan perikanan dalam pemanfaatan dan pengelolaannya tidak terlepas dari permasalahan. Isu-isu trend yang sering terjadi seperti konflik antar wilayah, hal ini sering dipicu oleh perebutan zona fishing ground, penggunaan alat tangkap yang tidak ramah lingkungan, daerah penangkapan yang semakin jauh, tingginya biaya operasional bahkan cenderung terjadi penangkapan yang berlebih (over fishing). Hal ini tentu membutuhkan peran Pemerintah untuk menentukan kebijakan dalam pemanfataan sumberdaya perikanan dan kelautan yang ramah lingkungan dan berkelanjutan.

Sampai saat ini penangkapan ikan layang di Pulau Ternate masih bersifat open access (terbuka bagi setiap nelayan) atau jumlah upaya (purse seine) belum dikendalikan dan aturan sistim perizinan. Salah satu faktor yang perlu dimonitoring terhadap alat ini adalah hasil tangkapan per unit upaya atau Catch Per Unit Effort.

Jaring lingkar (purse seine), gill net hanyut, gill net tetap dan pukat pantai merupakan alat tangkap yang digunakan oleh masyarakat di perairan Pulau Ternate untuk mengeksplotasi jenis ikan layang (Decapterus $s p)$. Studi CPUE sumberdaya ikan pelagis yang tertangkap dengan menggunakan empat jenis alat tangkap yang beroperasi di Perairan Pulau 
Ternate perlu dilakukan sebagai pengaturan aktivitas pengelolaan sumberdaya ikan, dan merupakan suatu keharusan agar tersedia dasar kuat dalam menyusun kebijakan perikanan tangkap. Sampai saat ini juga diperlukan hasil tingkat pemanfaatan Catch Per unit Effort, penentuan Tingkat Potensi Lestari, Upaya optimum, dan Tingkat pemanfaatan sumberdaya ikan layang (Decapterus sp) di Ternate, dimana sampai saat ini belum. pernah diteliti, sementara informasi tersebut sangat dibutuhkan didalam pengelolaan perikanan secara berkelanjutan.

\subsection{Tujuan dan Manfaat Penelitian}

Penelitian ini bertujuan untuk menganalisis Potensi Lestari (Maximum Sustainable Yield) dan Upaya pemanfaatan optimum, tingkat pemanfaatan serta produksi CPUE, dari tahun 2008 sampai 2015 (8 tahun terakhir). Hasil penelitian diharapkan dapat dijadikan bahan pertimbangan dalam

pengelolaan ikan layang (Decapterus $s p$ ) secara berkelanjutan di perairan Pulau Ternate, Provinsi Maluku Utara, dan dapat menjadi bahan informasi dalam rangka penelitian lebih lanjut.

\section{METODE PENELITIAN}

\subsection{Waktu dan Tempat}

Penellitian ini untuk melihat potensi dan Ikan layang (Decapterus $s p$ ) di perairan Pulau Ternate, waktu penelitian selama 1 bulan dengan menggunakan data time series Dinas Kelautan dan Perikanan Kota Ternate. Data yang dipakai untuk analisis adalah data times series dengan interval waktu 8 tahun (2008 2015).

\subsection{Metode Pengambilan Data}

Penelitian yang digunakan adalah metode survey dan observasi langsung dilapangan, dimana data yang diperoleh meliputi data sekunder adalah sebagai berikut :

(1) Data Primer, merupakan data model pengoperasian alat tangkap yang digunakan untuk menangkap ikan layang (Decapterus sp) yang diperoleh dari hasil wawancara langsung dilapangan.

(2) Data Sekunder, merupakan data berkala (Time Series) hasil tangkapan dan upaya penangkapan dari tahun 2008 sampai dengan tahun 2015 di perairan Pulau Ternate. Pengumpulan data sekunder dilakukan penelusuran pustaka dan hasilhasil penelitian yang dilakukan pada berbagai instansi pemerintah.

\subsection{Analisis Data}

Data yang diperoleh berupa data jumlah effort per kecamatan, data produksi tahunan (catch) menurut jenis alat tangkap per kecamatan (ton), data produksi menurut jenis ikan per alat tangkap per tahun (untuk kecamatan), data produksi (catch) tahunan perjenis ikan per kecamatan. Data produksi yang diperoleh dijadikan sebagai bahan informasi untuk menganalisa MSY dan F-Opt (Effort/Upaya Maksimum) untuk jenis Ikan layang (Decapterus sp) di perairan Pulau Ternate, dimana analisis data melalui beberapa tahap yaitu :

\subsubsection{Analisis Produksi Per Alat Tangkap per \\ Kecamatan}

Data yang didapat dari Dinas Kelautan dan Perikanan tidak menampilkan data produksi per alat tangkap per jenis ikan untuk kecamatan sehingga data tersebut perlu di olah lagi untuk mendapatkan produksi per alat tangkap per jenis ikan dengan rumus :

$$
\mathrm{CPi}_{\mathrm{Pi}}=\left[\frac{\sum F i}{\sum F} \times 100 \%\right] x \boldsymbol{C t i}
$$

Dimana :

$$
\begin{aligned}
& \mathrm{C} p i=\text { Produksi/alat tangkap/jenis ikan } \\
& \Sigma F i=\text { Jumlah unit alat tangkap yang }
\end{aligned}
$$

2.3.2. Analisis Produksi Per Alat Tangkap per Jenis Ikan untuk perairan Pulau Ternate

Pangkalan pendaratan ikan untuk penangkapan di perairan Pulau Ternate umumnya berada pada beberapa kecamatan yang berada di wilayah Kota Ternate Provinsi Maluku utara, sehingga untuk analisis produksi per alat tangkap untuk perairan dibutuhkan data produksi beberapa kecamatan diantaranya Kec. Ternate Tengah, Kec. Ternate 
Utara, Kec. Ternate Selatan, Kec. Pulau Hiri Kec. Moti dan Kec. Batang Dua. Data ini dianalisis dengan rumus (Gulland, 1983):

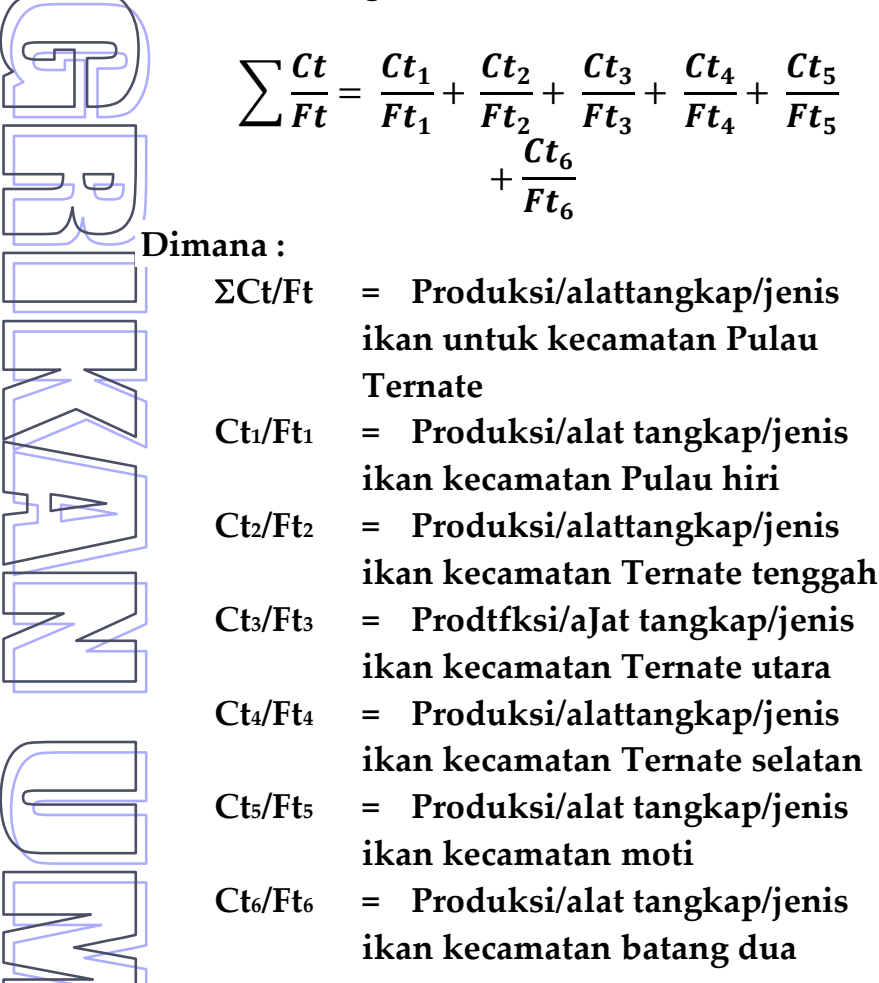

\subsubsection{Analisis Fishing Power Indeks (FPI)}

Unit effort sejumlah armada penangkapan ikan dengan alat tangkap dan waktu tertentu dikonversi ke dalam satuan "boat-days" (trip). Pertimbangan yang digunakan adalah :

(1) Respon stock terhadap alat tangkap standar akan menentukan status sumberdaya selanjutnya berdampak pada status perikanan alat tangkap lain,

(2) Total hasil tangkap ikan per unit effort alat tangkap standar lebih dominan dibanding alat tangkap lain, dan

(3) Daerah penangkapan alat tangkap standar meliputi dan atau berhubungan dengan daerah penangkapan alat tangkap lain.

Prosedur standarisasi alat tangkap ke dalam satuan baku unit alat tangkap standar, dapat dilakukan sebagai berikut alat tangkap standar yang digunakan mempunyai CPUE terbesar dan memiliki nilai faktor daya tangkap (fishing power index, FP1) sama dengan 1. Nilai FPI dapat diperoleh melalui persamaan (Gulland, 1983):

CPUE $_{r}=\frac{\text { Catch }_{r}}{\text { Effort }_{r}}, r=1,2,3, \ldots . P($ alat standarisasi $)$
CPUE $_{s}=\frac{\text { Catch }_{s}}{\text { Effort }_{s}}, s=1,2,3, \ldots . Q($ alat tangkap standar $)$ $F P I=\frac{C P U E_{r}}{C P U E_{s}}, i=1,2,3, \ldots K($ jenis alat tangkap $)$

dimana :

CPUEr $=$ total hasil tangkapan (catch) per upaya tangkap (effort) dari alat tangkap $r$ yang akan distandarisasi (ton/trip).

CPUE $_{s}=$ total hasil tangkapan (catch) per upaya tangkap (effort) dari alat tangkap s yang dijadikan standar (ton/trip).

Frii $=$ fishing power index dari alat tangkap i (yang distandarisasi dan alat tangkap standar)

\subsubsection{Analisis Effort Standart}

Nilai Fpii digunakan untuk menghitung total upaya standar dengan persamaan (Gulland, 1983) :

$$
E=\sum_{i=1}^{n} F P I_{i} E_{i}
$$

dimana :

$\mathrm{E} \quad=$ total effort atau jumlah upaya tangkap dari atat tangkap yang distandarisasi dan alat tangkap standar (trip)

$\mathrm{Ei} \quad=$ effort dari alat tangkap yang distandarisasi dan alat tangkap standar (trip)

\subsubsection{Analisis MSY dan F-Opt}

Estimasi potensi sumberdaya perikanan tangkap didasarkan atas jumlah hasil tangkapan ikan yang didaratkan pada suatu wilayah dan variasi alat tangkap per trip. Prosedur estimasi dilakukan dengan model Scheafer (1954) dan Fox (1970), dimana persamaan hasil tangkapan per upaya tangkap (CPUE), dianalisis dengan rumus :

$$
C P U E_{n}=\frac{\text { Catch }_{n}}{E_{n}}, n=1,2,3, \ldots . M
$$

dimana :

CPUEn $_{n}=$ total hasil tangkapan per upaya penangkapan yang telah distandarisasi dalam tahun $\mathbf{n}$ (ton/trip) 
Catch $_{\mathrm{n}}=$ total hasil tangkapan dari seluruh alat dalam tahun $\mathbf{n}$ (ton)

En = total effort atau jumlah upaya tangkap dari alat tangkap yang distandarisasi dengan alat tangkap standar dalam tahun n (trip).

Hasil tangakapan Maksimum Lestari (MSY) dapat diduga dari data masukan berikut :

$f(i)=$ upaya tahun $i, i=1,2, \ldots, n$

$\mathrm{Y} / \mathrm{f}=$ hasil tangkapan (dalam bobot) per unit upaya pada tahun $\mathrm{i}$

Cara yang paling sederhana untuk mengekspresikan hasil tangkapan per unit upaya (Y/f) sebagai fungsi daripada upaya (f) adalah model linier yang disarankan oleh Scheafer (1954). MSY dan F-Opt untuk model Scheafer (1954) adalah :

$$
\begin{aligned}
& \text { MSY }=\mathbf{a}^{2} / 4 \mathbf{b} \\
& \text { F-opt } / \text { FM5y }_{\text {M }}=-\mathbf{a} / \mathbf{2} \mathbf{b} .
\end{aligned}
$$

$$
\text { b = Slope }
$$

Nilai a dan $b$ didapat dengan menganalisis Effort-Standar sebagai variable bebas $(X)$ dan nilai $C_{P U E}=Y_{i} / F_{i}$ sebagai varibel tak bebas $(Y)$ sehingga didapat persamaan (Scheafer, 1954):

$$
\mathrm{Y}=\mathrm{a}+\mathrm{bx} \text { atau } \frac{Y_{i}}{F_{i}}=\mathrm{a}+\mathrm{b}^{*} \mathrm{f}(\mathrm{i}), \text { bila } \mathrm{f}(\mathrm{i}) \leq-\frac{a}{b}
$$

\section{HASIL DAN PEMBAHASAN}

3.1. Produksi Ikan Layang (Decapterus $s p$ ) Data Produksi perikanan tangkap Kota Ternate menunjukkan bahwa produksi ikan layang (Decapterus $s p$ ) selama 8 tahun terakhir (20082015) cenderung mengalami perubahan secara fluktuatif. Untuk analisis jumlah produksi ikan layang (Decapterus sp) di Perairan Pulau Ternate digunakan data laporan Dinas Kelautan dan Perikanan Kota Ternate dan Kantor Badan Pusat Statistik dari Tahun 2008 sampai tahun 2015 yang merupakan akumulasi dari 7 kecamatan. Gambar 3 menunjukan produksi ikan layang (Decapterus $s p$ ) selama tahun 2008 sampai 2015.

\section{Dimana : $a=$ intercept}

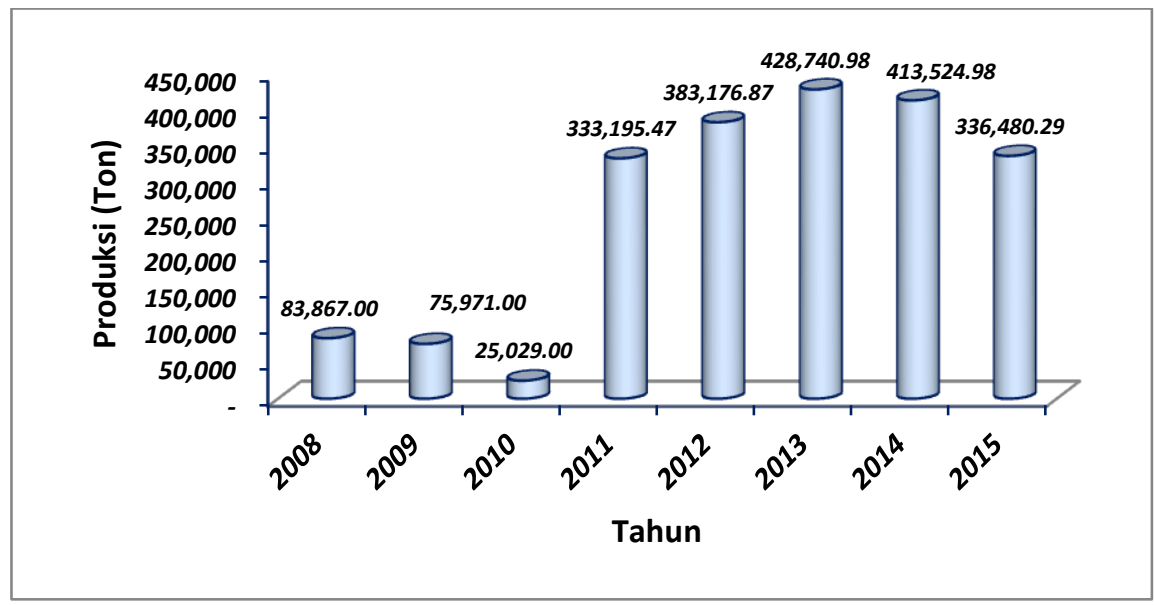

Gambar 3. Produksi Ikan Layang (Decapterus sp) di Perairan Pulau Ternate

Grafik pada Gambar 3 menunjukan fluktuasi produksi ikan Layang (Decapterus $s p$ ) diperairan Pulau Ternate. Secara umum nampak bahwa terdapat dua pola produksi, yakni pada tahun 2008 - 2010, dimana jumlah produksi pada 3 tahun tersebut produksi ikan layang (Decapterus sp) sangat kecil dan mengalami penurunan bila dibandingkan dengan produksi 5 tahun sesudahnya. Pada tahun 2011 terjadi peningkatan produksi secara terus menerus sampai tahun 2013, produksi tertinggi terdapat pada tahun 2013 dengan nilai produksi (427.740,98 ton/tahun) disebabkan meningkatnya upaya penangkapan. Tahun 2014 sampai 2015 Produksi menurun dengan laju penurunan yang lambat disebabkan upaya penangkapan menurun.

Apabila penangkapan berlangsung secara terus menerus tanpa pengaturan dan pengendalian maka kapasitas pertumbuhan populasi suatu saat nanti tetap akan menurun sehingga akan berbahaya terhadap kelestarian populasi ikan layang (Decapterus sp). Kecenderungan terjadinya fluktuasi terhadap 
tingkat produksi ikan layang (Decapterus spp) (Decapterus sp) dari tahun 2008 sampai tahun 2015 merupakan salah satu gejala perubahan tingkat populasi ikan layang yang disebabkan oleh banyaknya upaya penangkapan. Adapun analisis produksi sumberdaya ikan layang di dalam penelitian ini, difokuskan pada produksi ikan layang dengan upaya penangkapannya adalah jumlah alat tangkap. Dengan asumsi bahwa seluruh hasil tangkapan di perairan
Pulau Ternate tercatat dalam data produksi ikan layang di Dinas Kelautan dan Perikanan dan Badan Pusat Statistik Kota Ternate. Trip penangkapan ikan merupakan kegiatan operasi penangkapan ikan sejak unit penangkapan ikan meninggalkan pangkalan menuju daerah operasi, mencari daerah penangkapan ikan, melakukan penangkapan ikan, sampai kembali lagi ke tempat pangkalan asal atau ke tempat pendaratan yang sama.
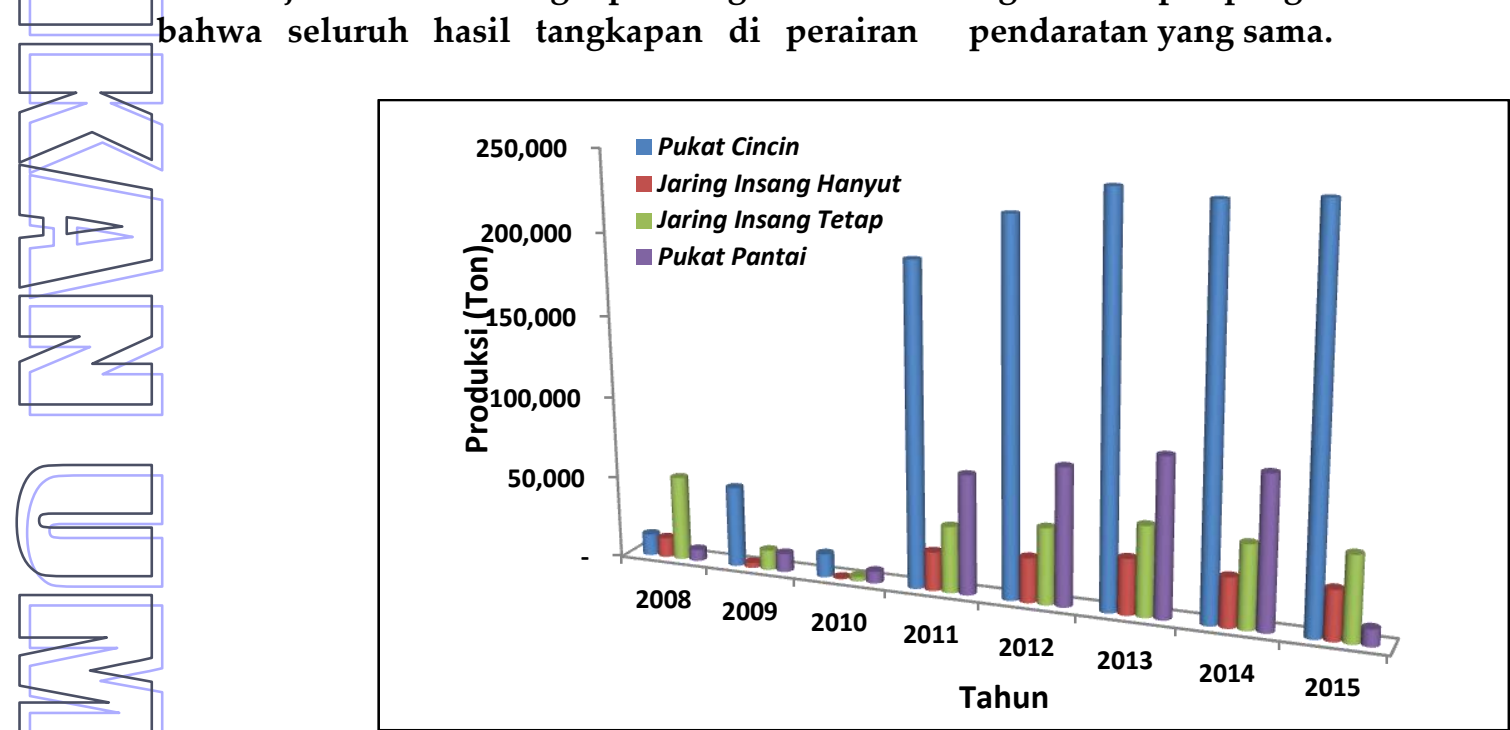

Gambar 4. Produksi Ikan layang Per Jenis Alat Tangkap Tahun 2008 - 2015

Gambar 4, menunjukan produksi ikan layang (Decapterus sp) per jenis alat tangkap yang dioperasikan oleh nelayan di perairan pulau Ternate, dimana terlihat bahwa jenis alat tangkap dengan produksi terbanyak adalah jenis alat tangkap pukat cincin atau purse seine sehingga untuk analisis tingkat pemanfaatan alat tangkap pukat cincin inilah yang dijadikan sebagai alat tangkap standar.

Unit penangkapan ikan merupakan satu kesatuan teknis dalam operasi penangkapan ikan. Unit penangkapan ikan terdiri atas perahu atau kapal penangkap ikan, alat penangkap ikan dan nelayan, dimana ketiganya saling berkaitan dan saling menunjang. Penangkapan ikan layang (Decapterus $s p$ ) di perairan Pulau Ternate yang menggunakan beberapa jenis unit alat tangkap diantaranya pukat cincin/purse seine, jaring insang hanyut, jaring insang tetap dan pukat pantai, dengan tingkat produksi masing-masing alat tangkap dapat dilihat pada Gambar 4.

Gambar 5, menunjukan bahwa dapat dilihat bahwa jenis alat tangkap yang digunakan untuk menangkap ikan layang (Decapterus $s p$ ) di
Perairan Pulau Ternate umumnya merupakan alat tangkap yang bersifat aktif, dimana jenis alat tangkap keseluruhan yang digunakan adalah 4 jenis alat dengan alat tangkap jaring lingkar/purse seine merupakan alat tangkap yang mobilitasnya lebih besar, kemudian diikuti oleh jenis alat tangkap pukat pantai, jaring insang tetap dan jaring insang hanyut, sehingga sesuai Gambar 7, maka jenis alat tangkap yang digunakan sebagai alat tangkap standar dalam Fishing Power indeks $\left(F_{P I}\right)$ untuk prosedur analisis estimasi MSY dan $\mathbf{F}_{\mathrm{MSY}} / \mathbf{F}_{\mathrm{Opt}}$ di Perairan Pulau Ternate adalah alat tangkap purse seine karena alat ini sifatnya yang aktif dalam menangkap ikan layang (Decapterus $s p)$.

\subsection{Upaya Penangkapan}

Faktor berpengaruh terhadap penurunan populasi ikan layang (Decapterus $s p$ ) adalah pertambahan jumlah upaya penangkapan (trip). Upaya penangkapan (trip) di perairan Pulau Ternate dari tahun 2008 sampai 2015 dapat dilihat pada Gambar 6.

Gambar 6, dapat dilihat fluktuasi upaya penangkapan ikan layang di Perairan Pulau Ternate. Upaya penangkapan ikan layang di perairan Pulau Ternate umumnya di lakukan 
dengan empat jenis alat tangkap yakni pukat cincin, jaring insang tetap, jaring insang hanyut dan pukat pantai. Upaya penangkapan dari empat jenis alat tangkap yang digunakan untuk menangkap ikan layang (Decapterus $s p$ ) terlihat

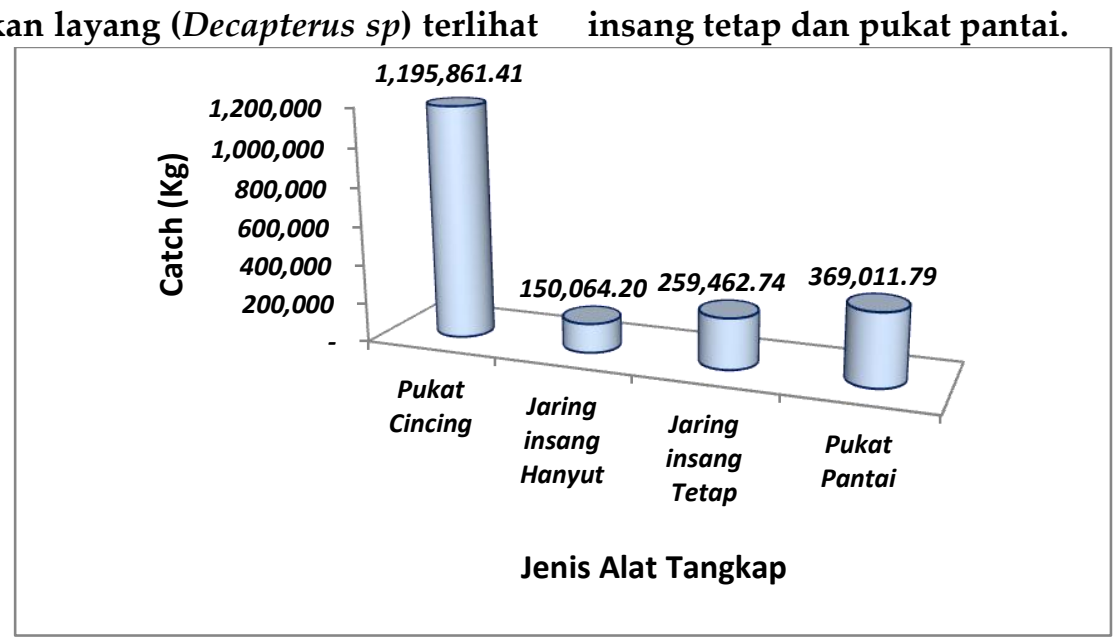

Gambar 5. Produksi Per Jenis Alat Tangkap Yang Di Gunakan Untuk Menangkap Ikan Layang (Decapterus sp) di Perairan Pulau Ternate

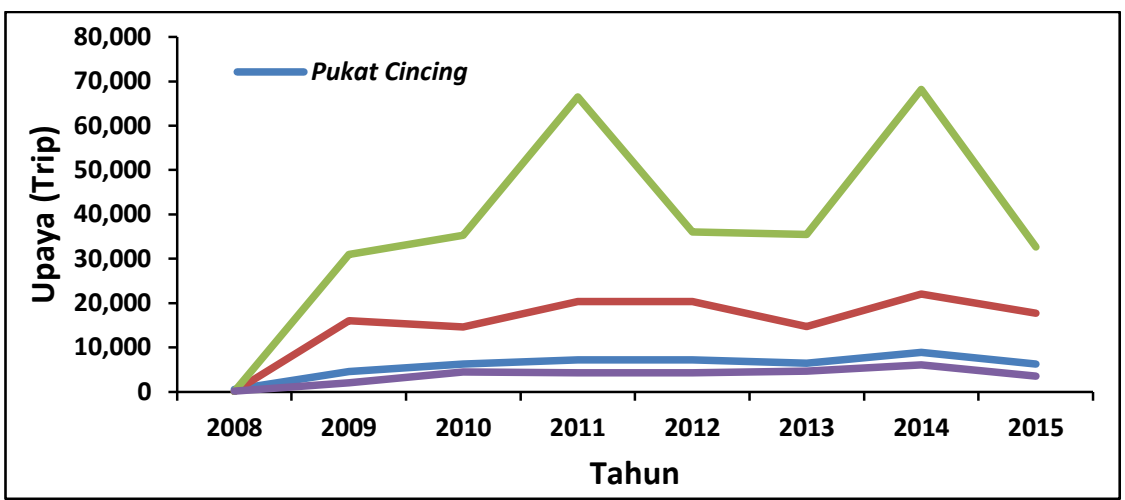

Gambar 6. Upaya (trip) Per Jenis Alat Tangkap Tahun 2008-2015 sangat fluktuatif, dimana upaya penangkapan tertinggi dari ke empat jenis alat tangkapterdapat pada jenis alat tangkap pukat cincin, kemudian jaring insang hanyut, jaring insang tetap dan pukat pantai.

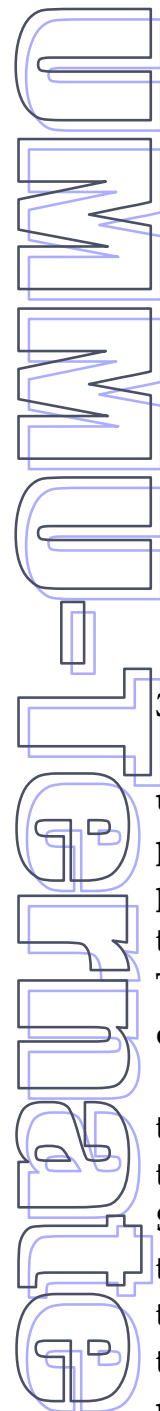

3.3. Hasil Tangkapan Per Unit Upaya (CPUE)

Perubahan hasil tangkapan per unit upaya atau Catch Per Unit Effort (CPUE) sangat penting dalam pengawasan dan pengendalian penangkapan sumberdaya perikanan. Hasil tangkapan per unit upaya di perairan Pulau Ternate dari Tahun 2008 sampai 2015 dapat dilihat pada Gambar 7.

Gambar 7, dapat dilihat bahwa hasil tangkapan per unit upaya tertinggi terjadi pada tahun 2015 dengan 38.74 ton per trip. Sedangkan hasil tangkapan per unit upaya terendah terjadi pada tahun 2008 sebesar 0.04 ton per trip. Secara umum nampak bahwa terdapat dua pola hasil tangkapan per unit upaya (CPUE), pada tahun 2008 sampai tahun 2010 CPUE relatif kecil, tahun 2011 sampai 2015 CPUE relatif meningkat.
Perubahan CPUE setiap tahun disebabkan karena fluktuasi hasil tangkapan dan besarnya beban biaya produksi dibanding keuntungan yang diperoleh. Hasil analisis ini sesuai dengan pernyataan Ali (2005), bahwa penambahan upaya penangkapan tidak dapat lagi meningkatkan CPUE atau penambahan upaya selalu diikuti dengan penurunan CPUE. Apabila penambahan upaya terus berlanjut, maka secara biologis berbahaya terhadap populasi dan akan menimbulkan kerugian ekonomi. Untuk itu pengaturan dan pengendalian upaya penangkapan sesuai dengan standar upaya optimum perlu dilakukan untuk menjaga keseimbangan biologis dan mencegah terjadinya kerugian usaha nelayan ikan layang. 


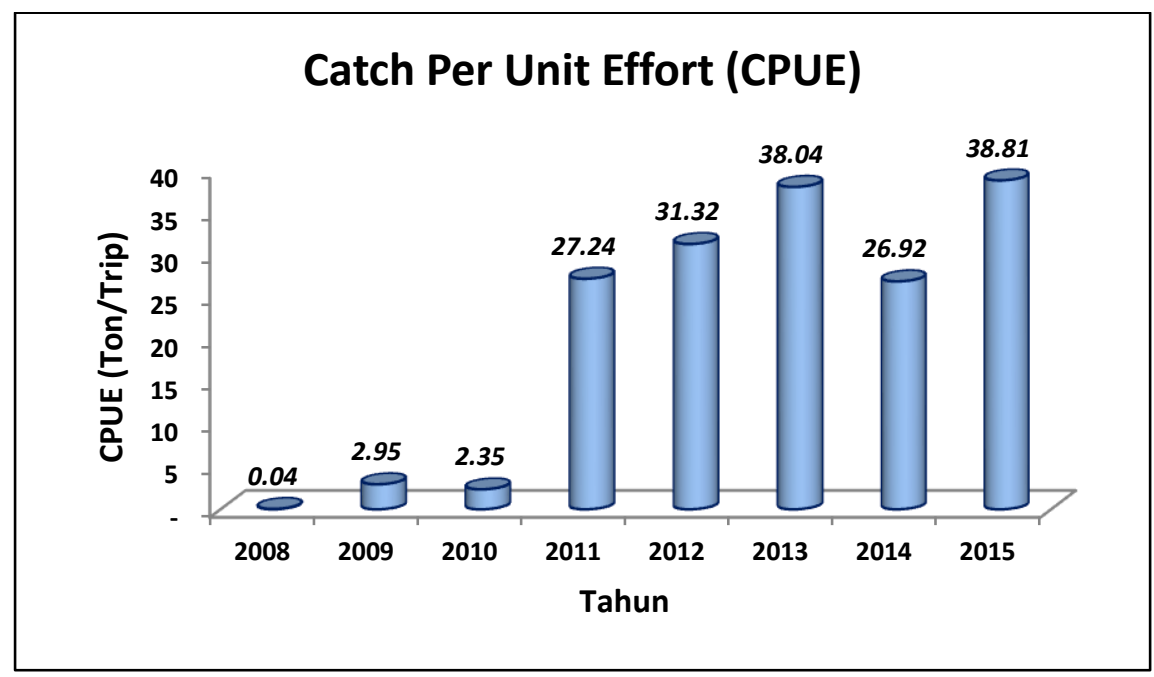

Gambar 7. Hasil tangkapan per unit upaya di tahun 2008 sampai 2015

\subsection{Hasil Maksimum Lestari (MSY)}

Hasil analisis maksimum lestari (Maksimum Sustainable Yield) adalah salah satu standar biologis yang digunakan dalam pengelolaan dan konservasi sumberdaya perikanan berkelanjutan. Penentuan standar biologis dalam penangkapan dapat digunakan pendekatan surplus produksi dengan metode Schaefer. Fluktuasi potensi lestari dan tingkat eksploitasi ikan layang di perairan Pulau Ternate dari tahun 2008 sampai 2015 (Gambar 3). Jumlah upaya penangkapan terlihat tidak tetap, untuk jumlah trip berkisar antara 8,685.38 sampai 18,929.46 trip. Dalam hal ini perubahan upaya penangkapan setiap tahunnya menunjukkan nilai yang begitu besar, sehingga bila terjadi penambahan upaya penangkapan yang tidak terkendali di tahun-tahun mendatang yang tentu sangat berpengaruh terhadap produksi per unit usaha (CPUE) sehingga dengan demikian penambahan upaya penangkapan harus dibatasi sesuai jumlah maksimal yang diperbolehkan. Nilai MSY sumberdaya perikanan dengan menggunakan model Schaefer adalah sebesar $311,506.493$ ton dengan upaya penangkapan atau tingkat eksploitasi optimum (F-optimum) setara dengan 10,765.155 trip.

Gambar 3, dapat dilihat fluktuasi tingkat pemanfaatan ikan layang di Perairan Pulau Ternate dari tahun 2008 sampai 2015. Tingkat pemanfaatan ikan layang terendah terjadi pada tahun 2008 dan 2010, sedangkan tingkat pemanfaatan tertinggi terjadi pada tahun 2011 sampai 2015. Pada tingkat pemanfaatan sejak tahun 2011 sesaui dengan hasil analisis umumnya telah melebihi potensi lestari atau MSY.

\subsection{Tingkat Pemanfaatan}

Fluktuasi tingkat pemanfaatan ikan layang (Decapterus sp) dapat disebabkan oleh berbagai factor, penurunan hasil tangkapan mungkin disebabkan karena menurunnya ukuran populasi akibat tingginya upaya penangkapan di tahun-tahun sebelumnya. Sebaliknya hasil tangkapan meningkat dapat disebabkan karena meningkatnya ukuran populasi akibat rendahnya upaya penangkapan ditahun sebelumnya, atau meningkatnya upaya itu sendiri akibat dorongan harga. Kurva hasil maksimum lestari ikan layang berdasarkan model Schaefer dengan persamaan sebagai berikut :

$$
Y i=58.065 f-0.0027 f^{2}
$$

Dimana Yi adalah hasil maksimum lestari dan $f$ adalah upaya penangkapan. Model Schaefer menghasilkan hasil tangkapan maksimum lestari (MSY) sebesar 311,506.493 ton dengan upaya optimal (Fmsy) setara dengan 10,765.155 trip penangkapan dari tahun 2008 sampai 2015 yang diobservasi (Gambar 10).

Gambar 11. dapat dilihat fluktuasi hasil tangkapan maksimum lestari (MSY) model Schaefer di perairan Pulau Ternate. Implikasi dari model tersebut diatas adalah jika standar acuan biologis MSY 311,506.493 ton dapat dicapai oleh standar upaya optimal (Fmsy) 
고릴

10,765.155 trip penangkapan. Berdasarkan data produksi ikan layang sejak tahun 2011 - 2015 upaya penangkapan (Ftrip) sudah melampaui upaya penangkapan optimum (Fmsy), ini menunjukkan bahwa pada tahun 2011 - 2015 telah terjadi kelebihan penangkapan (Over exploitation). Hal ini sesuai dengan pendapat (2005) yang menyatakan bahwa pengurangan dan penambahan upaya bergantung pada potensi lestari dan tingkat pemanfaatan tahun sebelumnya. Kesinambungan data dalam waktu yang tepat pada akhir periode dapat membantu dalam menetapkan dan mengatur upaya yang akan beroperasi pada tahun berikutnya.

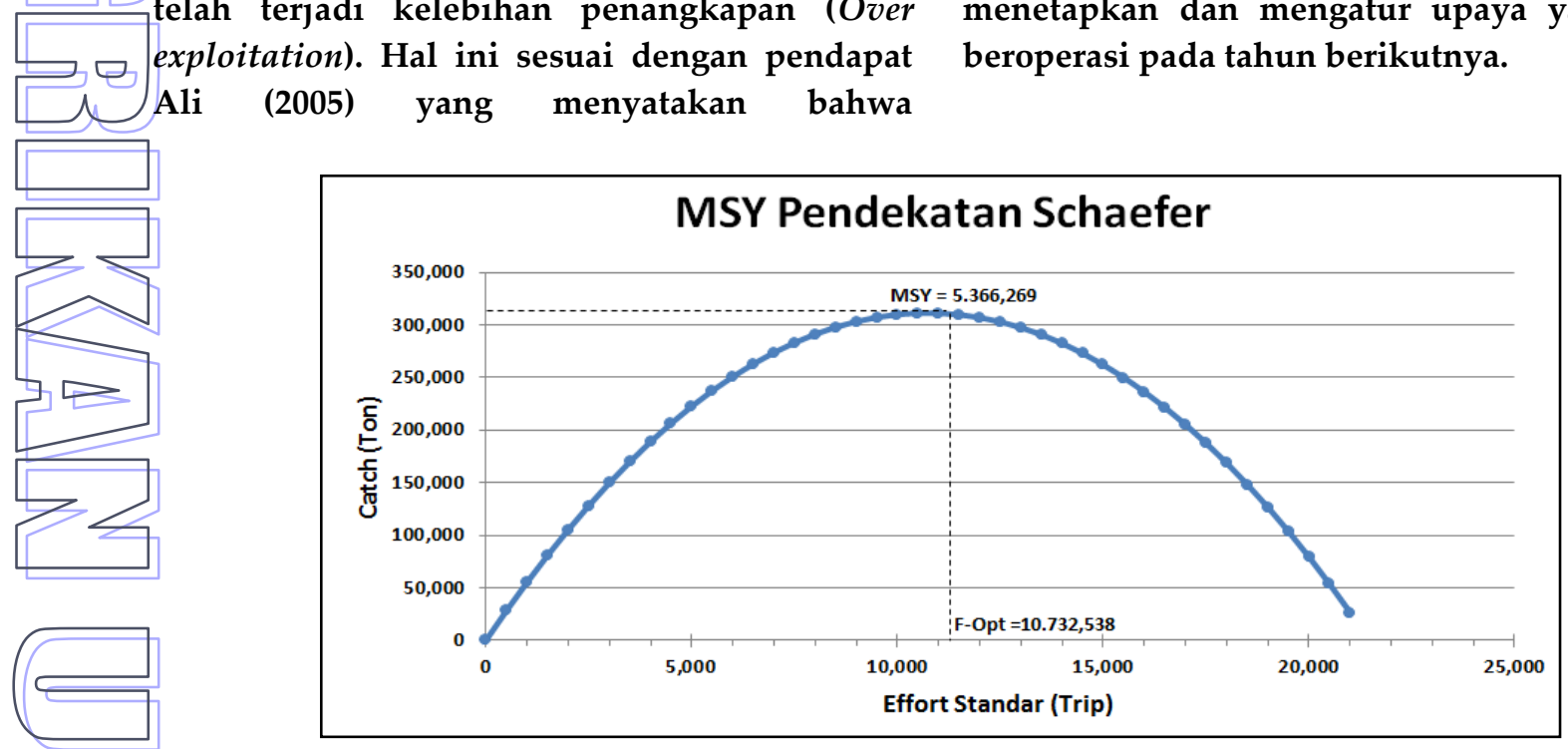

Gambar 8. Kurva Hasil Maksimum Lestari Model Schaefer

Salah satu tangung jawab utama membatasi atau mengembangkan upaya khususnya bagi pengelola sumberdaya perikanan di perairan Pulau Ternate yaitu harus menentukan tingkat eksploitasi alat tangkap, dimana tingkat eksploitasi alat tangkap tersebut berhubungan langsung dengan potensi lestari (MSY) sumberdaya perikanan. Dengan mengetahui tingkat eksploitasi alat tangkap, diharapkan terwujudnya suatu keseimbangan antara potensi lestari (MSY) sumberdaya perikanan dengan pemanfaatannya sehingga kelestarian sumberdaya perikanan dapat terjamin. Hingga saat ini, pengelolaan sumberdaya perikanan yang berhubungan dengan tingkat eksploitasi alat tangkap di Negara-negara maju dilakukan melalui suatu kebijakan diantaranya penentuan kuota penangkapan, pembatasan jumlah alat tangkap, penetapan daerah penangkapan (fishing ground) yang bertujuan untuk penangkapan.

\section{PENUTUP}

Hasil penelitian dapat di simpulkan bahwa besarnya potensi lestari (MSY) ikan layang (Decapterus $s p$ ) di perairan Pulau Ternate adalah sebesar 311,516.493 ton/tahun dengan upaya optimum (F-Opt) adalah 10,765.155 trip/tahun, tingkat pemanfaatan maksimum yang di ijinkan adalah sebesar $80 \%$ dari MSY sehingga tingkat pemanfaatan maksimumnya adalah sebesar 249,205.19 ton/tahun. tingkat pemanfaatan potensi ikan layang (Decapterus sp) di Perairan Pulau Ternate sejak tahun 2011 sampai 2015 telah melebihi dari potensi lestari ikan tersebut sehingga perlu adanya pembatasan jumlah upaya pemanfaatan agar dapat menjaga kelestarian ikan layang (Decapterus sp) di Perairan Pulau Ternate.

\section{DAFTAR PUSTAKA}

Ali, S. A. 2005, Kondisi Sediaan dan Keragaman Populasi Ikan Terbang (Hirundichtys oxychepalus Bleeker, 1852) di Laut Flores dan Selat Makassar. Disertasi. Program Pascasarjana Unhas. $282 \mathrm{p}$.

Baskoro, M. S dan Effendy, A., 2005. Tingkah Laku Ikan : Hubungannya dengan Metode Pengoperasian Alat Tangkap Ikan. Departemen Pemanfaatan Suberdaya Perikanan. IPB. 
Bogor.Saanin, H. 1984. Takonomi dan kunci Identifikasi Ikan. Jilid I dan II. Bina Cipta. Bogor.

Coleman, F. C. And Williams, S.L. 2002. Overexploiting marine ecosystem enginers : Potential Consequences for Biodiversity : Trends in ecology and Evolution 17: 40-44.

Dahuri R., Jacub Rais., Sapta Putra Gading., M. J. Sitepu., 2004. Pengelolaan Sumber Daya Wilayah Pesisir dan Lautan Secara Terpadu. Edisi Revisi. PT. Pradnya Paramita. Jakarta.

FAO, 1983. FAO Species Cataloque Vol. 2 Scombrids of The World An Annotated And llustratted Cataloque of Tunas, Mackerel, Bonitas and Related Species Known to Date. Rome. UN.

Genisa, A. S., 1999. Pengenalan Jenis-Jenis Ikan Laut Ekonomis Renting di Indonesia. Jurnal Oseana ISSN 0216-1877. No 1 Hal: 17 - 38.

Gulland, J. A. 1971. Fishing and The Stock of Fish at Iceland. U.K. Min. Af:ric. Fish., Fish. Invest, (ser. 2), 23 (4): 52 pp.

Gulland, J. A. 1983. Fish Stock Assessment : Manual of Basic Methods. Food and Agriculture Organization of The United Nation. Rome. John Wiley \& Sons, Singapore, 223 pp.

Gunarso, W. 1985. Tingkat Laku Ikan dalam Hubungannya dengan Alat, Metoda dan Teknik Penangkapan. Diktat Kuliah Jurusan Pemanfaatan Sumberdaya Perikanan. Fakultas Perikanan Institut Pertanian Bogor. Bogor.

Hela, L dan Laevestu, T. 1970. Fisheries Oceanograhy. Fishing News (Books) LTD. London.

Iversen, E.S. 1996. Living marine resources, their utilitation andmanagement. Champman and Hall Newyork

King, M and A. Me flgorm., 1989. Fisheries Biology and Management of Pasific Island StudentInternational DEVELOPMENT Program of Australian Universities and Collages. 67 p.

Monintja, D. R, R. Yusfiandayani., 2001. Pemanfaatan Sumberdaya Pesisir Dalam Bidang Perikanan Tangkap. Presiding Pelatrhan Pengelolaan Wilayah Pesisir Terpadu. IPS. Bogor.

Nontji. A. 2002. Laut Nusantara. Djambatan. Jakarta.
Saanin, H. 1984. Takonomi dan kunci Identifikasi Ikan. Jilid I dan II. Bina Cipta. Bogor.
Sadhori, N. 1985. Teknik Penangkapan Ikan. Angkasa. Bandung.
Sudirman, H. dan Mallawa, A., 2004. Teknik Penangkapn Ikan. Cetakan Pertama. PT. Rineka Cipta.
Jakarta. 